DOI: $10.22616 /$ j.balticsurveying.2018.010

\title{
THE CITTASLOW MOVEMENT IN RURAL AREAS - A CASE STUDY OF A VILLAGE IN THE POLISH REGION OF WARMIA AND MAZURY
}

\author{
Katarzyna Pietrzyk \\ University of Warmia and Mazury
}

\begin{abstract}
The international Cittaslow movement brings together towns that promote the slow life philosophy. The concept has been developed in response to the increasing pace of life and the adverse effects of globalization. According to the members of Cittaslow, the organization contributes to the sustainable development of their regions and to improvement of the quality of life. In view of the benefits of Cittaslow membership confirmed by research studies, the question arises whether the concept of Cittaslow could also be introduced in rural areas. This paper seeks to answer the above question. The study involved an analysis of the Cittaslow membership criteria (Cittaslow goals) and a survey conducted among the inhabitants of the Warmian village of Żabi Róg. The results of the study were used to test the research hypothesis and to assess the quality of life in the analyzed area.

Keywords: rural areas, quality of life, slow life, Cittaslow
\end{abstract}

\section{Introduction}

The slow life concept has been gaining increasing popularity in the $21^{\text {st }}$ century. A fast-paced life and a multitude of responsibilities have disrupted the harmony of human existence. A need was born for an idea that would remedy these problems while preserving a high standard of living. The slow life philosophy draws upon centuries of tradition in various cultures and religions (Buddhism, Christianity) to promote the idea of modern life that is based on mindfulness, inner reflection, richness of simplicity, modern solutions that respect tradition, culture, the natural environment and sustainable development. Mostly slow life organizations focus their activities in large cities and highly urbanized areas that are most susceptible to negative consequences of globalization. However, the slow life movement has not been sufficiently adapted to the specific needs of rural areas (Botta 2016).

The main aim of the research was to show whether the Cittaslow concept can also be implemented in rural areas. The village was analyzed on the basis of a modified and expanded certification procedure for Cittaslow candidates. At the same time, this study is an attempt to evaluate the quality of life in a village in the Polish Region of Warmia and Mazury based on the criteria for Cittaslow accreditation, which is an intermediate goal. The outcomes were compared with the results of a local community survey to determine whether the fundamental principles of the slow life movement can be adapted to rural areas, and to evaluate the perceived standard of living in the village of Żabi Róg. The analysis of the type has never been conducted in Poland or in other countries, and the present study is the first attempt to transfer the Cittaslow concept to rural areas.

\section{Rural areas}

In the second half of the 20th century the rural area was defined as the area of the state with low population density, whither dominate agricultural activity also forestry and fishing. Which was often identified with the use of land, leaving aside the social aspect - this concept was quickly considered wrong. This is strongly emphasized by the present research, which consider the rural area as a complex phenomenon with many features. In the 1990s you could easily see approaches close to nowadays, the rural area was considered to be an area outside the city border, which is distinguished by a number of different or similar statistical indicators, for example: population density, agrarian structure, occupational activity rates, etc. (Bański i Stola 2002). Today, it is emphasized that defining a rural area requires flexibility, and any definition at the time of creation may become obsolete or incomplete. It is accurate to say that there is a "discourse to recognize them as a multifunctional 
space, taking into account both the features of the diversification of the functional structure of the local economy and human communities" (Stanny 2014, p. 128).

The aforementioned changes in rural areas in the 21 st century will occur in a very dynamic way. It is difficult to determine what direction they will take, because there are many global and local trends in the world. They have a significant impact on the shape of the Polish countryside. The orientation most often presented is focused on counteracting the basic problems of modern times, such as disorders of demographic structure, social problems, monofunctionality, deficiencies in social and technical infrastructure (Bański 2013a). Not only the phenomenon of globalization causing excessive competitiveness, discrimination of rural areas outside the suburban zone, but also the development of agricultural technology, Internet networks, increasing the pool of external subsidies, and scientific and technical solutions is still a major impact on the rural areas. It is related to the need to adapt Polish rural areas to global trends, especially economic ones. Uniformity of the world leads to the necessity of finding unique features of the region, original food products. This is how the next trend is shaped: localization characterized by adapting modern solutions and technologies to the potential and resources of a given place. In recent years more and more often this trend can be found in the Polish countryside, where the local population, its value, culture and history are appreciated. Recent publications emphasize that the best solution is to combine the two trends described above, and both their positive and negative features are a developmental stimulant. Researchers particularly stress the negative transformations and their effects, environmental and climate disasters. The surface of natural spaces is reduced in favor of anthropogenic ones, but the concept of primary landscape has no reference in reality. At the same time, increasing social awareness causes the formation of proecological organizations, repeated use of raw materials, renewable energy sources, renewal of forgotten plants, breeding of endangered animal species and many other activities. Trends and directions of changes are many more, and how the future will look like we will learn only after some time (Banski 2013b).

\section{Methodology of research and materials}

The village of Żabi Róg is situated in the Polish Region of Warmia and Mazury, Ostróda county, Morąg municipality (Fig. 1). According to German historical sources, the village was founded in 1340. Its name has changed for multiple times over the centuries, from Złoty Róg to Róg, Górniki and, ultimately, Żabi Róg in 1947 (Pociag do przeszłości ...2008).

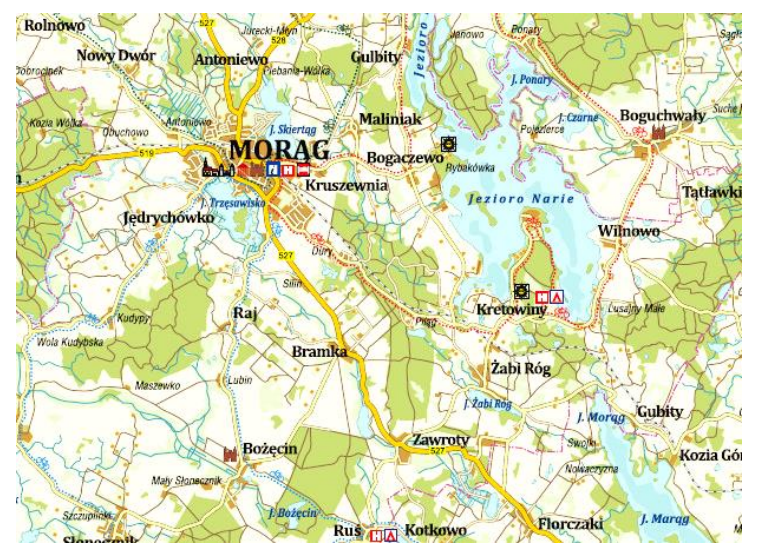

Fig. 1. Location of the village of Żabi Róg

Source: Renewal Plan for Żabi Róg Village for 2014-2020. (2013)

Żabi Rog is the largest village in the Morag municipality with an estimated population of 1,200 people. The village has a railway station, and it is also connected with the regional cities by a network of county and regional roads. Żabi Róg is surrounded by picturesque forests and lakes, Lake Żabie is situated in the Centre of the village. There are several farms in the village, but agricultural production is not the main source of income in the area due to poor geomorphological conditions (Renewal Plan for... 2014). 
It is worth mentioning how land use planning works in the area of the village of Żabi Róg. The first planning document that allows you to keep harmony in the area of the village is "Study of conditions and directions of spatial development of the commune of Moragg. Area of the City and Rural Areas". It covers the whole area of the village, defines the basic principles of spatial policy of the region, and its findings are binding for the authorities when creating new local zoning plans. The second extremely important document is Resolution No. VI / 44/11 of February 24, 2011, regarding the adoption of a local zoning plan for the commune of Morąg within the geodesic area of Żabi Róg. The plan covers as much as $45.5 \%$ of the area of the village of Żabi Róg, the remaining $54.5 \%$ (land not covered by the plan) are mainly agricultural, forest and meadow areas. This enables the maintenance of spatial order in the central part of the village, stimulates the proper development of social and technical infrastructure. Analyzing the graphic part (Fig. 2) of the local plan for the village of Żabi Róg, the dominance of agricultural land can be observed (129.22 ha), a significant role is played by farm buildings, farms and horticultural farms ( $81.11 \mathrm{ha}$ ), single-family housing, service areas (61.70 ha) and forests $(44.98 \mathrm{ha})$. The smallest area was allocated for cultural services, areas of technical infrastructure and water supply.

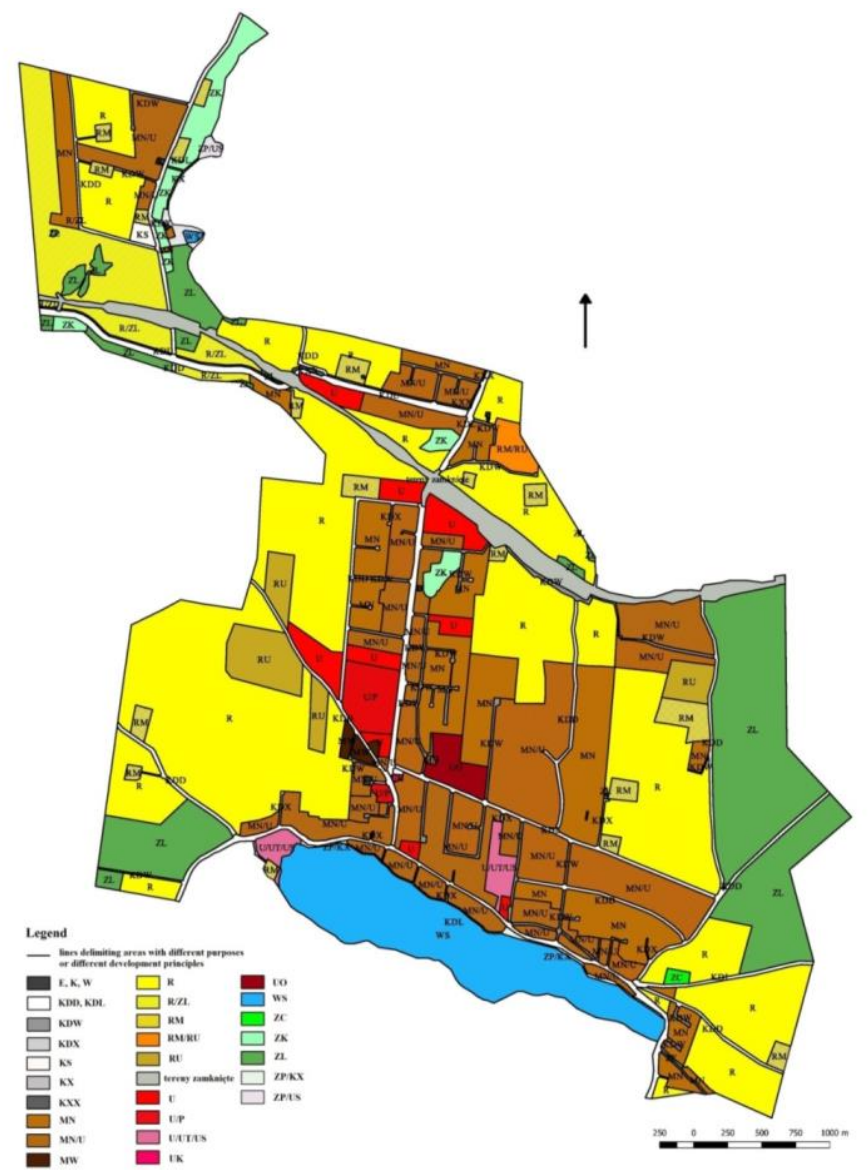

Fig. 2. Local spatial development plan for the village of Żabi Róg

Legend: E-areas of technical infrastructure-electrical power engineering; K-areas of technical infrastructuresewerage; KDD-areas of public access roads; KDL-areas of public local roads; KDW-areas of internal roads; $\mathrm{KDX}$-areas of pedestrian and footpath; KS-parking; KX-areas of pedestrian routes; KXX-areas of walking and cycling routes; MN- areas of single-family housing; MN/U areas of single-family housing/areas of service development; MW-areas of multi-family housing; R-agricultural areas; R/ZL- agricultural areas with the possibility of afforestation; RM- areas of farm buildings on farms, farms and horticulture; RM/RU- areas of farm buildings on farms, farms and horticulture as well as production areas on farm and fishing farms; RU- areas for production services on farms, farms, horticultural and forest and fishing farms; U- areas of service development; $\mathrm{U} / \mathrm{P}$ - areas of service development/areas of production facilities, warehouses and warehouses; U/UT/US-areas for service development/tourism areas/areas for sports and recreation services; UK- areas of cultural services; UOareas of education services; W-areas of technical infrastructure - waterworks; WS- areas of surface water inland; 
ZC-cemetery; ZK-natural and landscape greenery; ZL-forests; ZP/KX-greenery areas and walking routes; ZP/US - greenery areas, sports and recreation.

An attempt was made in this study to determine whether rural residents adhere to the slow life philosophy and whether villages should be incorporated into a slow life organization. The local standard of living was evaluated with the use of the self-assessment procedure for Cittaslow candidates applicable to Polish cities. The results of the evaluation were analyzed to determine whether the Cittaslow network should be expanded to include rural areas or whether the slow life concept should be transposed to the rural setting as part of a separate organization such as Villageslow. A separate rural organization would have to develop its own charter because the Cittaslow International Charter applies only to urban areas. The results of the assessment were also used to discuss the possible charter of a slow village organization in areas relating to membership fees, support for village administrators in the certification procedure, and candidate admission criteria. The quality of life was evaluated based on the modified self-assessment process for Cittaslow applicants. The potential candidate in this case would be the village of Żabi Róg which should score at least $50 \%$ in the evaluation, but unlike in the Cittaslow network, none of the criteria were obligatory. The above provision has been introduced on account of the fact that Polish rural areas differ considerably in their level of development. Separate groups and criteria have been introduced in the self-assessment process for rural areas. According to the Cittaslow charter, cities are evaluated based on 72 criteria in 7 policy areas. The rural accreditation requirements have been adapted to local needs, and the introduced modifications are presented in Table 1 . The modified classification process for rural area consists of 40 criteria divided into 6 policy areas.

Table 1

Cittaslow accreditation criteria modified for rural areas

\begin{tabular}{|c|c|c|c|}
\hline $\begin{array}{l}\text { Policy } \\
\text { area }\end{array}$ & Criteria & $\begin{array}{l}\text { Policy } \\
\text { area }\end{array}$ & Criteria \\
\hline \multirow{7}{*}{ 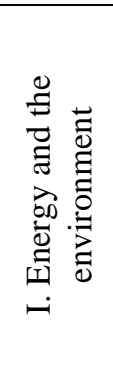 } & Air quality conservation & \multirow{7}{*}{ 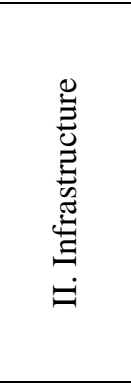 } & Efficient cycle paths \\
\hline & $\begin{array}{l}\text { Water quality conservation and water } \\
\text { consumption }\end{array}$ & & Length and quality of roads \\
\hline & $\begin{array}{l}\text { Selective waste collection, landfills, } \\
\text { composting bins }\end{array}$ & & Quality of public transport \\
\hline & Wastewater treatment & & Elimination of architectural barriers \\
\hline & Energy conservation & & Access to public services \\
\hline & Reduction of visible pollution, traffic, noise & & Access to basic services (shops, schools) \\
\hline & Preservation of biodiversity & & Employment, unemployment, commuting \\
\hline \multirow{6}{*}{ 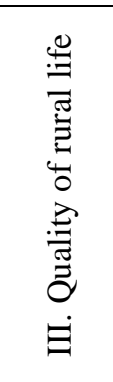 } & Initiatives promoting rural development & \multirow{6}{*}{ 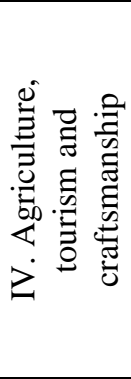 } & Development of organic farming \\
\hline & $\begin{array}{l}\text { Support for families and development } \\
\text { programs }\end{array}$ & & $\begin{array}{l}\text { Promotional of traditional work methods and } \\
\text { occupations }\end{array}$ \\
\hline & Sustainable land use & & Use of local products \\
\hline & Internet access & & $\begin{array}{l}\text { Taste education and promotion of local } \\
\text { products }\end{array}$ \\
\hline & \multirow{2}{*}{$\begin{array}{l}\text { Creation of spaces for the } \\
\text { commercialization of local products }\end{array}$} & & $\begin{array}{l}\text { Preservation and appreciation of local cultural } \\
\text { events }\end{array}$ \\
\hline & & & Additional hotel/restaurant capacity (diversity) \\
\hline \multirow{8}{*}{ 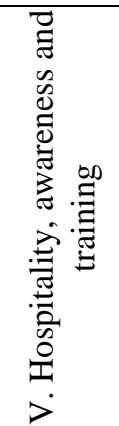 } & Hospitality and warm welcome & \multirow{8}{*}{ 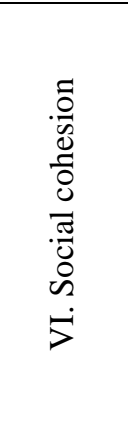 } & Social problems - low percentage \\
\hline & $\begin{array}{l}\text { Increasing the awareness of operators and } \\
\text { traders }\end{array}$ & & Degraded ad devastated areas \\
\hline & Slow routes (cycling, historical, etc.) & & Integration of persons with disabilities \\
\hline & Health education (combatting obesity) & & Youth status \\
\hline & Local initiatives & & Reduction of poverty \\
\hline & Cooperation with other organizations & & Community building \\
\hline & Support for Cittaslow campaigns & & Political participation \\
\hline & $\begin{array}{l}\text { Use of the Cittaslow logo on headed paper } \\
\text { (in the future) }\end{array}$ & & Youth activity centers \\
\hline
\end{tabular}

Source: made by the authors based on the Cittaslow International Charter 2017 
The self-assessment procedure for Cittaslow candidates is long and detailed. Therefore, a grading scale was developed for the needs of this study. In the proposed system, candidates that do not meet a given requirement are also evaluated for their growth potential and the efforts undertaken to achieve specific goals. Every criterion was analyzed and validated based on the documents and information obtained from the Morąg Town and Municipality Office or other public institutions. The grading scale was adapted to the needs of the study based on the fulfillment of every criterion: the criterion has been met (+), the criterion can be met (0), the criterion has not been met (-), data not available (nd).

The second research method was a survey, and a dedicated questionnaire was developed to survey the opinions of Żabi Róg residents. The surveyed population consisted of 25 persons who accounted for around $2 \%$ of the local population. The questionnaires were hand delivered to members of the local community and were completed anonymously by the respondents. The questionnaire contained 9 open-ended questions written in casual language (Apanowicz 2002).

\section{Discussions and results}

The quality of life in the village of Żabi Róg was evaluated based on a modified self-assessment procedure for Cittaslow candidates (Table 1). The evaluation was conducted based on 40 criteria divided into 6 policy areas. The results were presented separately for each of the 6 policy areas as well as cumulatively for the village of Żabi Róg to provide a detailed overview of the criteria where the village did and did not meet the $50 \%$ threshold.

Energy and environmental policies were the first analyzed area (Fig. 3) with 7 criteria relating to the availability and quality of the local utility networks (water supply, sewage disposal, power grid, municipal heating, gas supply). Air and water quality, biodiversity, pollution, noise and waste management were evaluated in the environmental dimension.

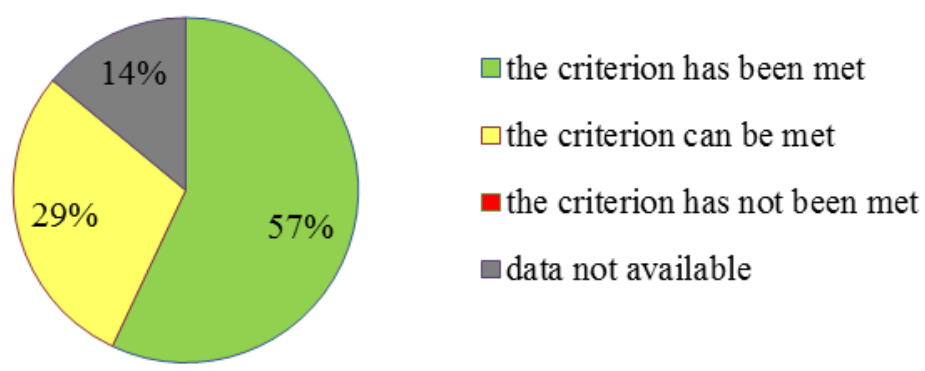

Fig. 3. Score in the energy and environmental policy area

The analyzed village met $57 \%$ of the requirements (4 out of 7 ) in the energy and the environment policy area. Żabi Róg has a sewage network, a water supply network and a biological wastewater treatment plant. Only several households in the outskirts of the village do not have access to public utilities (criteria: Wastewater treatment, Water quality conservation and water consumption). Municipal authorities initiated biodiversity protection measures, they manage Lake Żabie, regularly stock the lake and prohibit boat fishing. The village is surrounded by forests, and the land-use types indicated in the local zoning plan include forests, public greens and agricultural areas (criterion: Preservation of biodiversity). All households have an access to the power grid, and energy conservation campaigns are conducted locally (criterion: Energy conservation). The following two criteria can be met because the village has a high energy and environmental potential. The municipality has the required resources, procedures, structures and facilities for fulfilling the described requirements. Household waste is collected on selected days of the week and is processed by a professional operator in Morag. Many households have composting bins. There are no selective waste collection schemes, and the local residents are reluctant to sort waste (criterion: Selective waste collection, landfills, composting bins). Traffic is low, the village can be accessed by several roads, and it is situated in the proximity of a regional road that shifts some of traffic away from local roads. Information about traffic noise was not available. There are no polluting businesses in Żabi Róg. The village is not connected to a municipal heating network, and households are equipped with largely 
outdated coal-fired furnaces which contribute to local pollution (criterion: Reduction of visible pollution, traffic and noise). Data on air quality and air protection were not available.

Rural areas require efficient infrastructure policies (Fig. 4). In the infrastructure policy area, the village was analyzed based on 7 criteria relating to the labor market, unemployment, roads, pavements, public transport and architectural barriers. Easy access to public and social services contributes to social cohesion in rural areas.

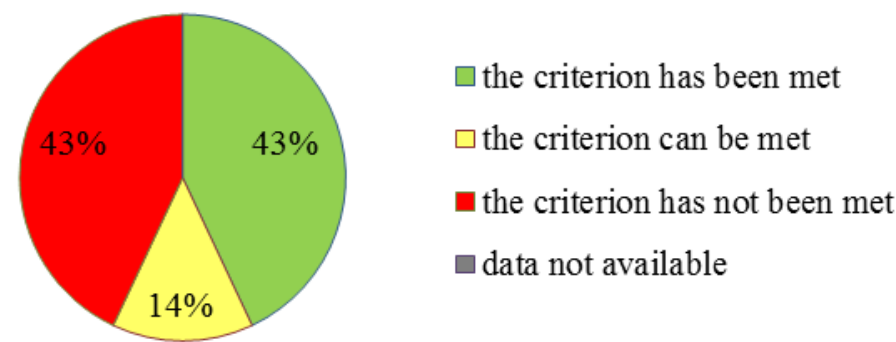

Fig. 4. Score in the infrastructure policy area

The Renewal Plan for Żabi Róg Village (2014) indicates that the village has not met the criteria relating to employment, unemployment and commuting. The village has a thriving labor market in comparison with the surrounding areas, but most businesses are construction companies, carpentry companies, gravel mines and food retailers. There are 6 medium-sized farms in Żabi Róg. Not all residents are able to find work locally, and many of them are employed in the nearby cities of Olsztyn and Ostróda. Commuting is difficult because the village is situated around $1 \mathrm{~km}$ away from a railway station, and public transport is slow due to the poor condition of local roads. Unemployment is relatively high, and around 160 residents were unemployed at the time of the study. The village has low infrastructure standards, in particular in the area of transport. There are no paved cycle paths, and several foot paths and cycle paths have been trodden in the local fields. Paved sidewalks are in very poor condition, they are overgrown with grass, uneven and very narrow. They are found only in the central part of the village, usually on one side of the street only, with high curbs and no ramps (criterion: Elimination of architectural barriers). The length and quality of roads is a criterion that could be improved and fully met in the future. The village is conveniently located in the proximity of regional road No. 527. Żabi Róg can be accessed by several county roads which are in poor condition and do not have a paved shoulder. The remaining 3 criteria have been met. The local residents have satisfactory access to public transport, the village has a railway station with a regular timetable, and there are privately operated buses to Morąg and Olsztyn. Żabi Róg has a large primary school for both local residents and children from the surrounding villages. The local residents have access to basic services, several shops and a church. Public services are available in the town of Morag which is situated around $10 \mathrm{~km}$ from the analyzed village.

The following 5 criteria (Fig. 5) were evaluated in the quality of rural life policy area which has a positive impact on many aspects of community life. The relevant activities include the promotion of local attractions and products. Promotional measures contribute to an improvement in the quality of life and support local families. Internet access is also an important requirement in the $21^{\text {st }}$ century.

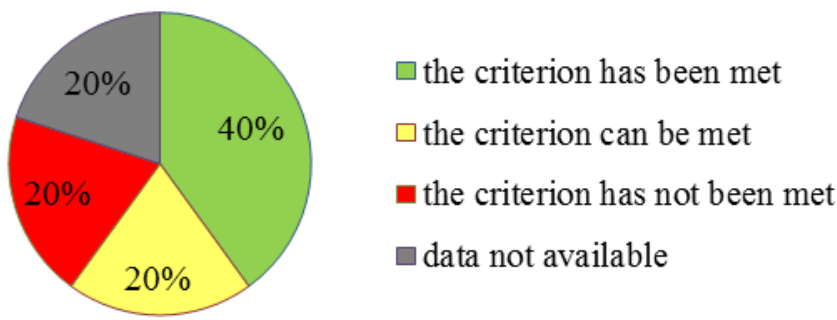

Fig. 5. Score in the quality of rural life policy area 
The local authorities undertake various initiatives to promote local attractions and products. Information brochures are published, the village has a music band, its own anthem, songs and ballads commemorating local traditions and heritage. Workshops and festivals are frequently organized, and the inhabitants eagerly promote the region and regional products in local markets, local customs festivals, culture and food fairs. Żabi Róg meets the land-use criterion. The local zoning plan was developed in 2011, and the village has a satisfactory agrarian structure. The criterion relating to the creation of spaces for the commercialization of local products can be met. Commercial facilities could be created in rural community centres, the local school and shops. At present, local products are sold only during municipal fairs. There are no dedicated measures and projects to support families and local development. The residents are entitled only to standard welfare. Żabi Róg has only wireless Internet access.

Agriculture, tourism and craftsmanship play very important roles not only in rural development, but in the entire slow life philosophy. These activities promote local agriculture and local produce. The development of tourism in Żabi Róg was evaluated based on its hotel and restaurant capacity.

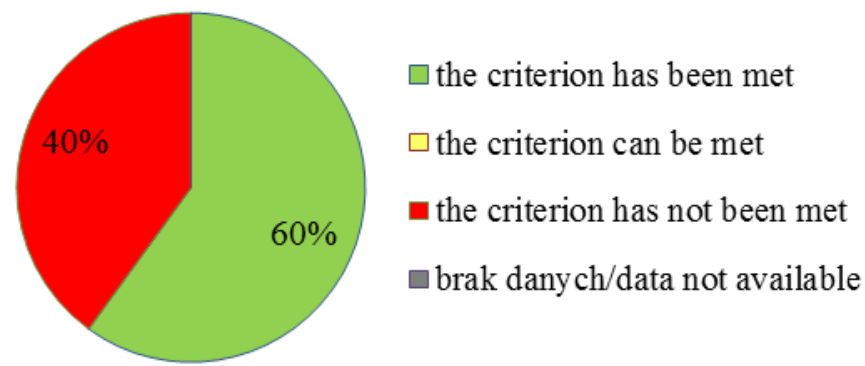

Fig. 6. Score in the agriculture, tourism and craftsmanship policy area

The criterion relating to the development of organic farming cannot be presently met for a number of reasons. Żabi Róg has a small number of farms that produce mostly cereal crops, and the local inhabitants are reluctant to work in agriculture. Tourist facilities are very limited. The village has only one guest house (Stara Szkoła) and no restaurants or bars. The remaining criteria have been met (Fig. 6). The local residents regularly organize cultural events, theater trips and concerts. They attend municipal fairs and events, such as the Harvest Festival, and celebrate local holidays. Community members use and promote local products, and craft artists create handmade objects.

Hospitality, awareness and training constituted the fifth evaluated policy area. The surveyed respondents were asked to voice their opinions about local organizations, cooperation with other organizations, health education, and customer service standards in retail and tourism (Fig. 7).

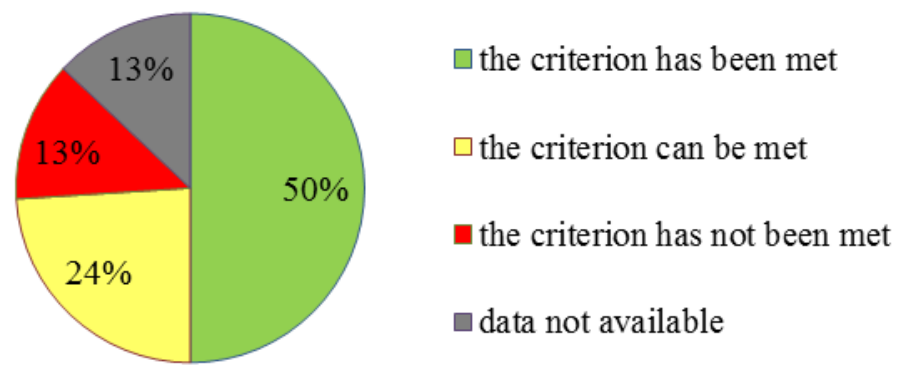

Fig. 7. Score in the hospitality, awareness and training policy area

The fifth policy area was difficult to assess due to scant data and the fact that many criteria had to be evaluated subjectively by the author. The local guest house (Stara Szkoła) has high customer service ratings on the Internet. The author (who is not a resident of Żabi Róg) has been served politely and competently in all local shops. Community members organize many local events such as bonfires, New Year's parties, carnival events, family fairs, Saint John's and Saint Andrew's Eve celebrations, Secret Santa gift exchanges, state holiday celebrations and trips to cultural institutions. The village 
has two community centres and a library. Żabi Róg collaborates with various organizations, including the Rural Support Foundation, municipal authorities in Morąg and other rural institutions. The local residents would gladly support Cittaslow campaigns; therefore, this criterion is likely to be met in the future. The slow routes criterion has not been met, and the progress made in the area of health education could not be analyzed due to the lack of data.

Social cohesion can be analyzed in various contexts in relation to different age groups, professional groups and social groups.

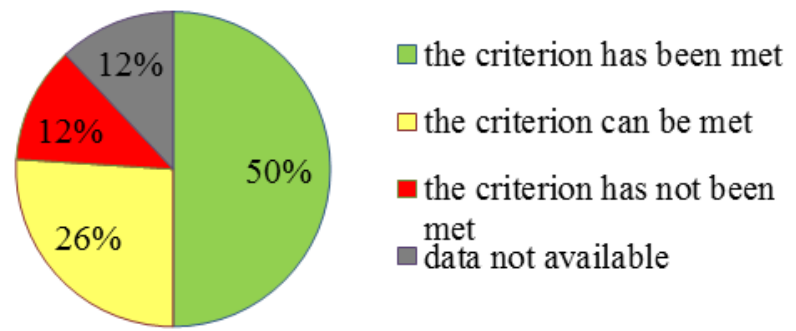

Fig. 8. Score in the social cohesion policy area

A half of the criteria in the social cohesion policy area have been met (Fig. 8). The residents of Żabi Róg frequently stage local initiatives, which significantly contribute to social cohesion. They are eager to join interest groups and bands. The village runs two community centres that are open to both young children (with supervision) and adolescents. The local residents participate in political life, vote in elections, and voter turnout is usually high during village elections. There are no damaged or devastated areas in the village. Several old buildings and the railway station require upgrading. The criteria that can be met in the future include a low percentage of social problems, integration of persons with disabilities, and reduction of poverty. The prevalence of social problems is low in Żabi Róg, and most of them can be remedied through dedicated support programs. Most of the problems are associated with poverty, unemployment, low coping skills and alcohol abuse. The progress in integrating people with disabilities is difficult to assess due to the absence of quantitative data. The only criterion that cannot be met is an improvement in the youth status after graduation.

Żabi Róg should meet at least $50 \%$ of the criteria to be eligible for membership in a slow life organization. The analyzed village scored exactly $50 \%$ in the evaluation. The following $20 \%$ requirements can be met, which is a promising outcome for local development and improvement in the quality of life. Żabi Róg did not meet $20 \%$ of criteria, mainly in the areas of infrastructure as well as agriculture, tourism and craftsmanship. Data relating to compliance with 4 criteria (10\% of the evaluated elements) were not available.

The survey involved 25 local residents who were asked to express their opinions about the village and potential membership in a slow life organization in an anonymous questionnaire (Table 2).

Table 2

Respondents' age and gender

\begin{tabular}{|c|c|c|c|c|}
\hline Gender and age & Number of people & Percentage & Number of people & Percentage \\
\hline Women aged $<18$ years & 0 & $0 \%$ & \multirow{3}{*}{17} & \multirow{3}{*}{$68 \%$} \\
\hline Women aged $18-50$ years & 6 & $24 \%$ & & \\
\hline Women aged $>50$ years & 11 & $44 \%$ & & \\
\hline Men aged $<18$ years & 1 & $4 \%$ & \multirow{3}{*}{8} & \multirow{3}{*}{$32 \%$} \\
\hline Men aged $18-50$ years & 3 & $12 \%$ & & \\
\hline Men aged $>50$ years & 4 & $16 \%$ & & \\
\hline Total & 25 & $100 \%$ & 25 & $100 \%$ \\
\hline
\end{tabular}

At the beginning of the questionnaire, the respondents were asked to state their age and gender. The majority of the surveyed subjects were women $(68 \%)$ who were more eager to participate in the study than men. Respondents younger than 18 years were least numerous, probably because the questionnaires were handed out during school hours. The above can also be attributed to the fact that 
pensioners account for a large proportion of the local population. The questionnaire was developed to elicit opinions about the quality of local life without previous knowledge of the slow life philosophy. In successive parts of the questionnaire, the surveyed subjects were provided with a brief description about the main goals of the slow life movement, and were asked whether Żabi Róg could benefit from membership in such an organization. In the first question (Fig. 9), the respondents were asked whether Żabi Róg was a village with a high quality of life and a culture of good living.

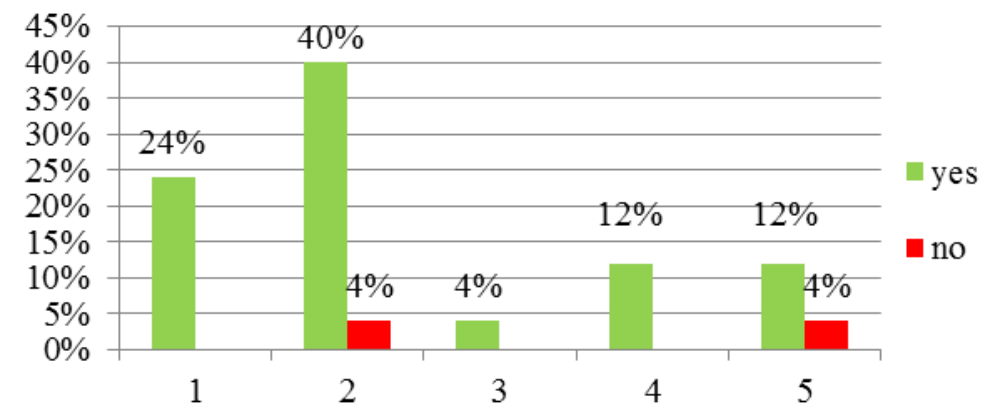

1. Women aged $18-50$ years, 2 . Women aged $>50$ years, 3 . Men aged $<18$ years, 4 . Men aged $18-50$ years, 5 . Men aged $>50$ years

Fig. 9. Respondents' opinions about the quality of life in Żabi Róg village

Nearly all respondents (92\%) were of the opinion that Żabi Róg was a friendly place to live. These answers constitute valuable inputs because the above opinion was expressed by permanent residents of the analyzed village.

The questions addressing the village's compliance with slow life criteria emphasized the importance of local initiatives. The surveyed residents were asked to voice their opinions on community involvement. Only $56 \%$ of the surveyed subjects recognized the importance of community involvement. Surprisingly, 24\% of the respondents were not aware that their neighbors had been involved in local initiatives. The above could be attributed to the fact that community initiatives in the village attracted regular groups of local activists. However, the respondents were aware that many local initiatives, community integration events, leisure time events and promotional activities were being organized in Żabi Róg. Thirteen respondents were able to identify 1 to 5 initiatives, 11 subjects -5 to 10 initiatives, and one respondent - more than 10 initiatives.

The question probing the respondents' familiarity with the slow life concept preceded the definition of the slow life philosophy to verify whether the movement was as popular in rural areas as in cities (Table 3).

Table 3

Familiarity with slow life and slow food concepts and the Cittaslow movement

\begin{tabular}{|l|c|c|}
\hline \multirow{2}{*}{\multicolumn{1}{|c}{ Gender and age }} & Familiarity with slow life and slow food concepts and the Cittaslow \\
& Yes & Novement \\
\cline { 2 - 3 } & $0 \%$ & $0 \%$ \\
\hline Women aged <18 years & $8 \%$ & $16 \%$ \\
\hline Women aged 18 - 50 years & $12 \%$ & $32 \%$ \\
\hline Women aged > 50 years & $0 \%$ & $4 \%$ \\
\hline Men aged <18 years & $4 \%$ & $8 \%$ \\
\hline Men aged 18 - 50 years & $4 \%$ & $12 \%$ \\
\hline Men aged $>50$ years & $28 \%$ & $72 \%$ \\
\hline Total & & \\
\hline
\end{tabular}

More than $70 \%$ of the respondents were not familiar with the slow life philosophy, which indicates that this concept is not popular in rural areas. The majority of the subjects who had heard of the slow life movement were women older than 50 years. Having read the short note describing the main goals of the slow life movement, $84 \%$ of the respondents agreed that Żabi Róg could benefit from membership in a slow life organization similar to the Cittaslow Association. Fourteen subjects were of the opinion that Żabi Róg meets the criteria required for membership in a slow life organization. 
The remaining 11 respondents were unable to answer this question and concluded that they needed more information about the slow life philosophy.

The respondents' opinions regarding the possible benefits of membership in a slow life organization are presented in Table 4.

Table 4

Benefits of membership in a slow life organization

\begin{tabular}{|c|l|c|}
\hline No. & \multicolumn{1}{|c|}{ Benefits of membership in a slow life organization for Żabi Róg } & Respondents \\
\hline 1. & Promotional advantages/Enhanced promotion of the member village & 21 \\
\hline 2. & "Slow" influx of tourists into the village & 11 \\
\hline 3. & Improved quality of the natural environment & 3 \\
\hline 4. & $\begin{array}{l}\text { Promotion of natural and environmentally-friendly food preparation } \\
\text { techniques/Promotion of regional and traditional cuisine }\end{array}$ & 13 \\
\hline 5. & Promotion of the village's cultural heritage and local traditions & 13 \\
\hline 6. & Improving the quality of life in the village & 16 \\
\hline 7. & Increasing environmental awareness among the inhabitants & 17 \\
\hline 8. & Promoting the culture of hospitality in the village of Żabi Róg & 2 \\
\hline 9. & Sustaining a sense of place and local identity & \\
\hline 10. & There are no benefits of membership & \\
\hline
\end{tabular}

The surveyed subjects recognized various benefits of membership in a slow life organization. Twentyone respondents were in favor of enhanced regional promotion. Surprisingly, 16 respondents were of the opinion that Żabi Róg could benefit from improvements in the culture of hospitality.

\section{Conclusions and Proposals}

This study evaluated the quality of life in the village of Żabi Róg based on compliance with the Cittaslow criteria and the opinions expressed by the local residents who participated in a questionnaire survey. The village has both strengths and weaknesses which are presented in Figures 39. For the needs of the study, the Cittaslow accreditation procedure has been adapted to the specific features of rural areas, and the results indicate that the Cittaslow movement could be expanded or that a separate slow life organization uniting rural areas could be established. However, the Cittaslow charter would have to be modified to achieve this goal. Villages are weakly populated, and they do not have city rights; therefore, population limits would have to be eliminated from the accreditation process for rural areas. The membership fees for rural areas would have to be considerably lowered or eliminated because the financial aspects of membership could discourage villages from joining the slow life movement. The accreditation procedure could pose a significant burden for village administrators who should be provided with significant support during the process. The village and its administrator should receive professional assistance in the process of filling out application documents. The assistant should reside in the village during the entire classification process. The present study marks the first stage of research which will be continued in other rural areas.

\section{References}

1. Apanowicz J. (2002) Metodologia Ogolna. Bernardinum. Gdynia. 85p. (in Polish).

2. Baldemir E., Kaya F., Sahin K. T. (2013) A Management Strategy within Sustainable City Context: Cittaslow, In: Özşahin M. (eds.) The Proceedings of 9th International Strategic Management Conference, Procedia - Social and Behavioral Sciences 99, ELSEVIER, p. 75 - 84.

3. Bański J. (2013a) On the future of the Polish countrysid. Studia Obszarów Wiejskich XXXI, PTG: PAN. IGiPZ Warszawa. p. 9-24.

4. Bański J. (2013b) Polish countryside in the perspective of 2050. Studia Obszarów Wiejskich, tom XXXIII, PTG: PAN. IGiPZ Warszawa. p. 9-22.

5. Bański J., Stola W. (2002) Changes in the spatial and functional structure of rural areas in Poland. Studia Obszarów Wiejskich, tom III. PTG: PAN. IGiPZ Warszawa. p.13-16.

6. Botta M. (2016) Evolution of the slow living concept within the models of sustainable communities, In: Ghisa M., Kapoor R. (eds.) Transforming Futures - a glimpse from the WFSF Conference 2013, Futures, vol. 80, ELSEVIER, Gangtok, p. 3-16. 
7. Cittaslow International Charter 2017. Available at http://cittaslowpolska.pl (accessed on 18/01/2018).

8. Kowalek E. (2008) Pociag do przeszlosci - stacja Zabi Rog. ADSUM. Zabi Rog. p.2-6 (in Polish).

9. Renewal Plan for Żabi Róg Village for 2014-2020. (2013) Resolution No. L/805/14 of 11 July 2014 approving the Renewal Plan for Żabi Róg Village for 2010- 2020. Morąg Town Office. p.1-20.

10. Stanny M. (2014) Village, rural area, rural population - about problems with defining them. Multidimensional look. Wieś i rolnictwo, Kwartalnik Nr 1 (162). IRWIR PAN. Warszawa. p. 123-138.

\section{Information about author}

Katarzyna Pietrzyk, University of Warmia and Mazury in Olsztyn, Faculty of Geodesy, Geospatial and Civil Engineering, Department of Real Estate Resources, ul. Prawocheńskiego 15, 10-720 Olsztyn, katarzyna.pietrzyk@uwm.edu.pl 